\title{
International For-Profit Investments in Microfinance Institutions Equity
}

\author{
Carlos Rodriguez Monroy, Ángel Huerga \\ Universidad Politécnica de Madrid (UPM), Banco Bilbao Vižaya Argentaria (BBVA) (Spain) \\ crmonroy@etsii.upm.es,_angel.huerga@gmail.com
}

\section{Abstrac:}

Purpose The purpose of this document is to review the funding options for Microfinance Institutions (MFIs), define the size of the holdings of international investors in MFI equity and in particular the MFIs listed in stock exchanges, analyze the characteristics of these subset of the financial world and study the stock exchange evolution of some listed MFIs amid the financial crisis.

Design/methoddogy/approadr: Since academic literature on listed MFI equity is virtually inexistent, most of the information has been obtained from the World Bank, annual accounts of the listed MFIs, stock exchanges and from equity research documents.

Findings: Microfinance Institutions share several common characteristics that make them a resilient business and the few MFIs that are listed in stock exchanges seem to have performed better in the financial crisis. Microfinance can be considered as one of the new frontiers of the expansion of the global banking industry.

Practical implications: Presently, international for-profit investors have very few ways of investing in microfinance equity. Most of the equity of the MFI equity is funded locally or thanks to the local public sector. The stock exchange listing of the MFIs should drive MFIs towards a more professional management, more transparency and better governance. 
Social implications: Microfinance Institutions provide credit to microenterprises in poor countries that have no other alternative sources of external capital to expand its activity. If global investors could easily invest in the listed equity of the MFIs these institutions would expand its lending books and would improve its governance, part of the population living in poor areas or with lower income could ameliorate its standard of living.

Originality/value The number of Microfinance Institutions that are professionally run like commercial banks is still scarce and even more scarce are the MFI listed in public stock exchanges. Therefore the published literature on the characteristics and performance of the listed equity of the Microfinance Institutions is extremely reduced. But microfinance assets are rapidly growing and MFIs will need to list their equity in stock exchanges to sustain this expansion.

Keywords: Microfinance Institutions, micro-credits, financial Institutions, equity, stock exchange

\section{The Boundaries of the microfinance market}

During the 1970s and 1980s, the microcredit movement started by Grammeen bank and others led to the emergence of nongovernmental organizations that provided small loans for the poor. In the 1990s, a number of these institutions transformed themselves into formal financial (Brand, 2010). Microfinance Institutions (MFI) are different from Commercial Financial Institutions mainly because are focused on providing funds (mainly in debt format) to poor people to invest in capital goods, based on the premise that the poor have skills that remain unutilized or underutilized but suffer from a lack of capital and cannot access to funding for their business (Feasley, 2011).

According the World Bank Development Indicators of 2009 there are 4.5 billion inhabitants in low income and middle lower income countries of which about 2.3 billion people have limited access to financial services. Some studies estimate that $60 \%$ of population have real demand for financial services (Brand, 2010; Cole, Simpson \& Zia, 2009) this may give an estimated total number of potential microfinance clients on $1.3 \mathrm{~b}$ people.

According to the MIX (Micro Finance Information Exchange, www.mixmarket.org) report 2010:

- The total loan portfolio of 1,896 MFIs reporting to the MIX database was at the end of 2009 of $\$ 142$ billion, which could be used as an estimation of the total microfinance market reached today.

- The total number of borrowers was 93 million, therefore the average loan amount per borrower was about $\$ 1,500$. 
- The average loan per borrower was about $\$ 1,500$

- The market is quite concentrated, and according to the January 2009 Fitch Ratings report and other sources, the 100 largest MFI account for $80 \%$ of total sector assets (Hamilton et al., 2009).

\begin{tabular}{|c|c|c|c|}
\hline Millions & $\begin{array}{l}\text { Total Population of the } \\
\text { Low Income Countries }\end{array}$ & $\begin{array}{l}\text { Potential Unbanked } \\
\text { Population }(50 \%)\end{array}$ & $\begin{array}{l}\text { Potential Microcredit } \\
\text { Clients }(60 \%)\end{array}$ \\
\hline Sub-Saharan Africa & 753 & 377 & 226 \\
\hline South Asia & 1.543 & 772 & 463 \\
\hline East Asia Pacific & 1.830 & 915 & 549 \\
\hline East Europe and Central Asia & 111 & 56 & 33 \\
\hline Middle East and North Africa & 280 & 140 & 84 \\
\hline Latin America & 73 & 37 & 22 \\
\hline Total & 4.590 & 2.295 & 1.377 \\
\hline
\end{tabular}

Figure 1. Potential MFI Clients (CGAP, 2011)

Using a conservative approach for the total sector demand, the figures stated by MIX indicate that currently only a small fraction of the 1.3 billion potential microfinance clients are reached. An extrapolation of the current loan levels to 1.3billion borrowers would show a total maximum theoretical market asset size of $\$ 1.9$ trillion. Other researchers (Dieckmann, 2008, 2009) using a much more restrictive social approach of microfinance, estimate that to fully satisfy the global demand for microfinance assets, the MFIs would need a total liabilities mix of debt, equity, deposits and subordinated debt of approximately $\$ 300 \mathrm{~b}$. In both cases it seems that only a small fraction of the total microfinance market is covered at present.

\section{The Funding of the Micro Finance Institutions}

Three main types of funding instruments can be distinguished (Brandt, 2010; Gonzalez, 2010):

- Own funds and equity. Donations, subsidies and grants, retained profits, in most cases equity investments by government agencies and individuals or in just a few cases private equity investments or equity raised in public stock exchanges.

- Debt in the form of grants, bonds or loans. Most MFIs cannot access the standard debt capital markets but MFIs can access the multilateral organizations and international development agencies (Non For Profit) and the For Profit specialized international investors: private institutional investors, international banks and Microfinance Investment Vehicles

- Retail deposits. Only the best and more professional microfinance institutions can take retail deposit, a characteristic that is normally only allowed to regulated banking institutions, due to the risk that this activity can entail for depositors. The access to retail deposits allows the escalation of the business 


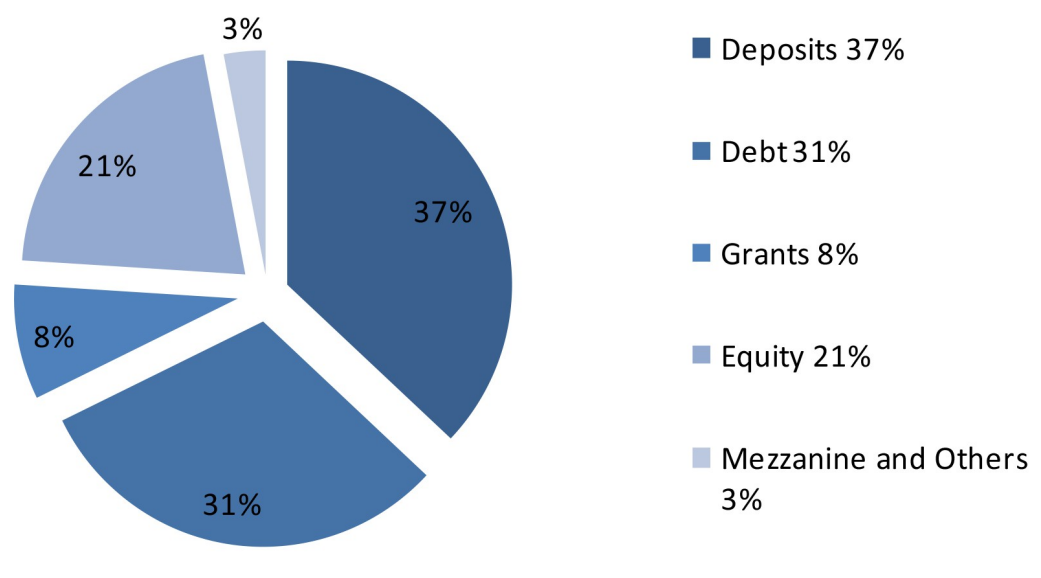

Figure 2. Committed Funding Amount by Instrument for MFIs (average) (CGAP, 2010)

According to the CGAP (Consultative Group to Assist the Poor) Microfinance survey 2011 and the MIX, the total amount of funds committed by international investors (Non For Profit and For Profit) to MFIs worldwide is about $\$ 60 \mathrm{~b}$ in the form of debt, guarantees, equity and other instruments. Most part of the funds are committed by local investors.

Also according the CGAP Microfinance survey 2011 and the MIX 52\% of the investments in MFIs are performed by both local and international For Profit investors, investors looking for a return to its investments. The rest are investments by multilateral and supranational organizations or by local governments or by individual donors looking or other social and development returns.

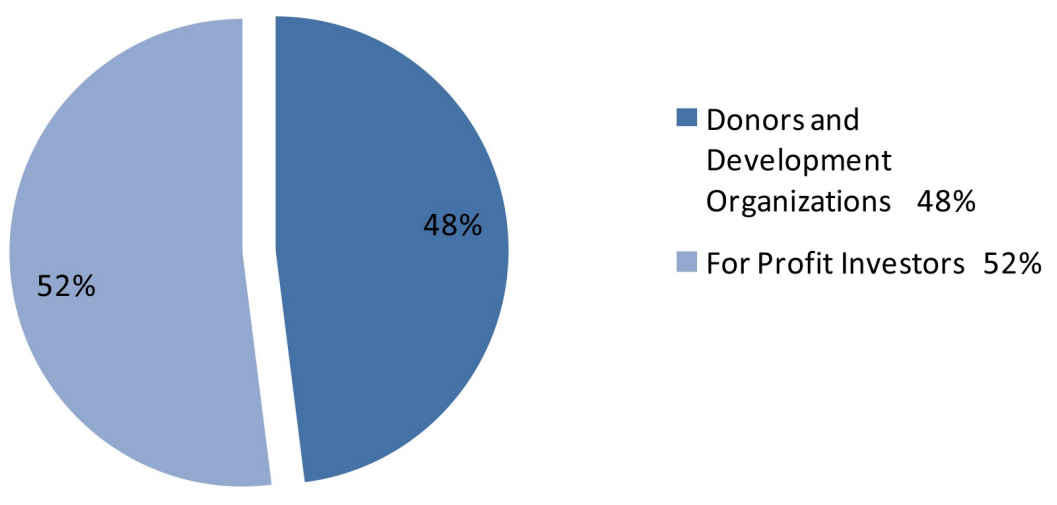

Figure 3. Total Average Committed Funding Amount by Type of Funder (CGAP, 2010)

\subsection{MFI Market Participants}

The graph below tries to shed clarity on the type of investors, the source of the investments, and the investments flows in the microfinance industry (Rozeira de Mariz, Reille, Rozas \& Kneiding, 2010; Brandt, 2010). The funds can go directly from the source investors to the MFIs in form of equity, debt, grants, guarantees or other instruments. In certain cases the funds are contributed to specialized funds, called Microfinance Investment Vehicles (MIVs) (Reille \& Glisovic-Mezieres, 2009). These MIV primarily invest in MFI debt and manage actively the exposure to the different underlyings and therefore are perceived as less risky than direct 
investments, although more expensive due to the management fees (Hechler-Fay d'herbe \& Luscher, 2008). At the end of 2010 there were 103 MIV with assets under management estimated of $\$ 6.6 \mathrm{~b}$ according to International Association of Microfinance Investors February 2010 and MIV Performance and prospects MIV Benchmark Survey CGAP, 2009.

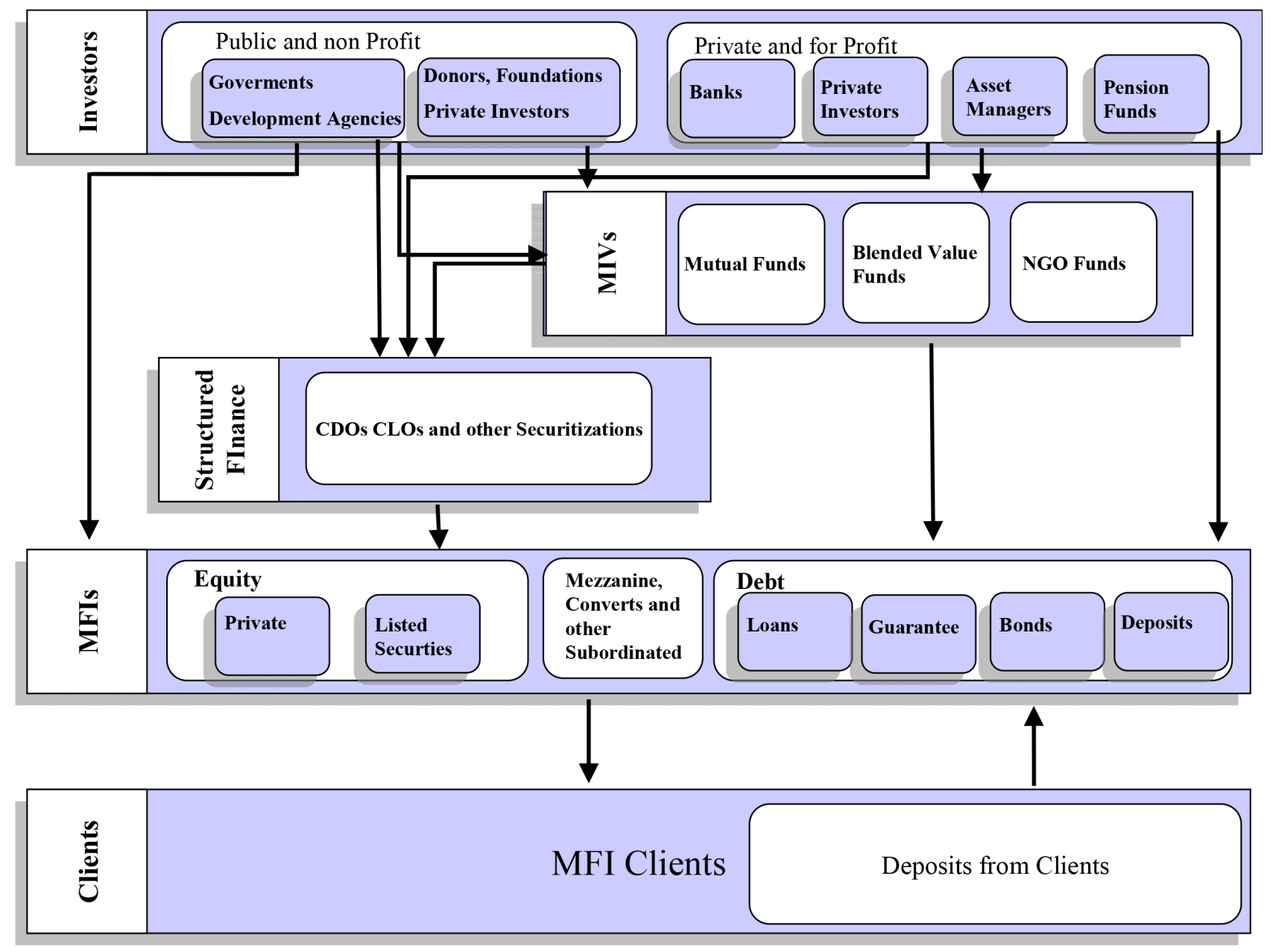

Figure 4. MFI Funding Market Participants

\subsection{Securitization}

Structured Finance Vehicles (SFV) were created in an attempt to market more easily the microfinance securities. The SFVs repackage a pool of loans and structure them in a way easer to buy from international investors, creating different seniority tranches in the event of default, offering different risk-return profiles adapted to investors that sometimes cannot face directly the risk presented by the MFIs. In other cases the MFI sells part of its loan portfolio, in the form of an asset backed security (ABS) through the true or synthetic sale of the assets (microcredits) in the balance sheet of the MFIs, delinking the credit risk of the originator from the credit risk of the assets themselves. The MFI originates the loans, creates the vehicle and in certain cases offers a first loss guarantee to the securitization vehicle, as a credit enhancement (Gupta \& Ramineedi, 2010b). Due to the short history of microfinance, all the transactions to date are structured as true sales and the synthetic securitization market or the covered bond market is not developed. The securitization process is presently used by the 
most important MFIs in Mexico, India and Indonesia. The benefits of the securitization of loans for the MFIs are:

- Expands the capacity of the MFI by selling part of its balance sheet

- MFIs can concentrate its efforts on originating loans and collecting payments

- MFIs diversify its funding sources

- MFIs remove risky assets from its balance sheet

\section{The size of the MFI Equity Market}

The vast majority of the funds committed to MFIs are in form of debt. The equity of the MFIs is provided mainly locally in each country but four main groups of international equity investors can be distinguished (Brand 2010; Gonzalez, 2010):

- Government development agencies, international development and supranational non for profit investors that normally invest in the form of private equity investments. The aggregate equity portfolio of these investors was valued at the beginning of 2010 on $\$ 761 \mathrm{~m}$ (based on the CGAP MIV 2011 survey and the MIX).

- MIVs and specialized investment funds with a focus on microfinance equity. Their total equity assets under management were estimated to have grown from $\$ 670 \mathrm{~m}$ in 2007 to $\$ 1.9 \mathrm{~b}$ at the beginning of 2010 (based on the CGAP MIV 2011 survey and the MIX).

- Large commercial private equity firms, such as Sequoia Capita, Legatum and others, the total amount invested by these institutions is estimated in excess of $\$ 400 \mathrm{~m}$ at the beginning of 2010 (Rozeira de Mariz et al., 2010).

- US pension funds such as TIAA CREF, and Netherlands ABP and PGGM which perform asset allocations as part of their socially responsible investment strategies and as a diversification. Their commitments are estimated to be $\$ 700 \mathrm{~m}$ at the beginning of 2010 (Rozeira de Mariz et al., 2010).

The four groups of international investors above give a total amount invested in microfinance equity of nearly $\$ 3.7 \mathrm{~b}$ at the beginning of 2010. As a reference for comparison, the total microfinance loan portfolio registered by the 2010 Mix survey showed an amount close to $\$ 142 \mathrm{~b}$. The asset base of the MFIs registered in the MIX database totalled assets of $\$ 180 \mathrm{~b}$. The total deposit base of the MFI institutions registered in the MIX was $\$ 27 \mathrm{~b}$. The funds and liabilities needed to match the assets should be composed of debt raised internationally, local debt, grants and donations, local government funds, cooperative funds, retained earnings, local equity, international equity investments and deposits from clients. The average proportion 
of equity in the balance sheet of the MFIS is close to $21 \%(\$ 38 b)$. Therefore the numbers show that most of this equity is funded locally or thanks to the local public sector and only a fraction (\$3.7b) is raised through international investors. The space for growth is very important, the MFIs should tap the international equity markets to maintain a sustained growth and international equty investors should play a very relevant role in the future.

\subsection{Listed MFIs}

The MFI is such a young subsector of the listed financial institutions globally that the number of listed MFI globally is extremely reduced. Under a restricted selection, there are six listed financial institutions that could be, in our view, considered Micro Finance Institutions:

- SKS Microfinance SKSMICRO: IN (India)

- Compartamos Banco COMPARTO: MM (México)

- Equity Group Kenya EQTY: NK (Kenya)

- Bank Rakyat Indonesia BBRI: IJ (Indonesia)

- Brac Bank BRAC: BD (Bangladesh)

- Financiera Independencia FNCRF: MM (México)

Additionally there are globally other seven listed financial institutions focused on low income clients or substandard borrowers, although in our opinion they cannot be considered as MFIs since they do not match the characteristics listed below, particularly the social objectives, broader client base, focus on working capital loan of microenterprises and risk management techniques.

- $\quad$ Capitec Bank CPI: SA (South Africa)

- Blue Financial Services BFS: SA (South Africa)

- International Personal Finance IPF: UK (UK, Mexico, Eastern Europe)

- African Bank (South Africa)

- Banco Panamericano (Brazil)

- Danamon Bank (Indonesia)

- First Cash Financial (US, Mexico) 
The listed MFI securities landscape will probably increase shortly, the assets are rapidly growing and the MFIs need new capital to expand their growing lending business and also because some initial investors in the early stages of the MFIs are now looking for an exit point. At least 2 other MFIs have plans to go public in India:

- Spandana Sphoorty (India)

- Share Microfinance (India)

\section{Common characteristics of the MFIs}

One of the objectives of this document is to define the specific characteristics of the MFIs that could lead to a different stock market evolution and perhaps could mean that MFIs can be considered a subset of the Emerging Markets Financial Institutions equity asset class.

\subsection{Social Objectives}

The MFIs provide financial services to the people previously unbanked, and help on the funding of the microenterprises that previously lacked of this support (Gupta \& Ramineedi, 2010a) (Rozeira de Mariz, Reille, Littlefield \& Kneiding, 2009). Despite some criticism there is a general consensus about the very positive social benefits of microfinance for poor societies (Byerlee $\&$ de Janvry, 2008).

\subsection{Reliable Debt Funding}

MFIs attract soft lending public organizations, supranational companies and socially responsible investors. These loans received by the MFIs tend to be:

- Below market rates (for the same risk profile)

- Longer maturities. The average maturity of the loans to MFIs from a international development organization is 60 months (Rozeira de Mariz et al., 2009)

- Loans are easily rolled over and emergency liquidity lines from public investors are available

This debt investor base tends to be more reliable. In the present financial crisis (2008-2012) the MFIs seem to have been less affected by market funding constraints, as they have had access to funding. These funders react differently to market difficulties, and when the credit squeeze is affecting global banks by making funds more difficult to obtain, more costly and only available in shorter maturities, the MFIs continued receiving loans from supranational institutions. However most of these funding by public investors is in hard currency (\$ or EUR), leaving the MFIs with a large and often unhedged foreign exchange exposures due to the likely 
depreciation of the assets in their balance sheet, denominated in the weak currencies of the local markets where they operate.

\subsection{Business Model}

MFIs asset and liability management enjoys a favourable duration mismatch, since their assets are short term (loans typically with maturities of less than one year) and liabilities are long term. Additionally MFIs client base operate in sectors of the basic economy, concentrated in the production or acquisition of essential products for local consumption. These sectors are less exposed to international economic adverse movements. It seems that MFIs are reaching an enormous part of the global economy that is more stable and that was previously unreachable.

\subsection{Stable Deposit Base}

Globally, as much as $37 \%$ of the balance sheet of the MFIs reporting to the MIX and CGAP is funded through deposits, most of them from its own client base. Retail deposits tend to be a very stable source of funding in emerging markets, especially in the lower income segment since they are less affected by competition and by adverse currency exchange movements. But not all the MFIs in all the jurisdictions have the ability to raise deposits from customers. The ability to raise deposits should give MFIs more resilience against future market movements.

\subsection{Low Financial Leverage}

In general MFIs have lower leverage than traditional banks (where leverage is defined as Total Equity/Total Assets, lower leverage means a higher equity ratio), this is probably due to the immaturity of the sector and the scarcity of standard debt funding for MFIs (Brand, 2010). According to the BIS the 15 year average Total Equity/Total Assets (leverage) of the banks in the developed nations reporting to BIS is $5.4 \%$. This same leverage ratio is close to $22 \%$ for MFIs reporting to the MIX.

\subsection{Relatively High ROE}

The ROE reveals how much profit a company obtained in comparison to the total amount of shareholder equity on the balance sheet, but this ratio is influenced by the capital structure of the company. The more leveraged a company the higher the ROE is. Despite the fact that most MFIs have a social objective, the ROE of the MFIs that are profitable tend to be very high (Feasley, 2011). And most important the financial leverage of the MFIs is very low compared to standard banks. 


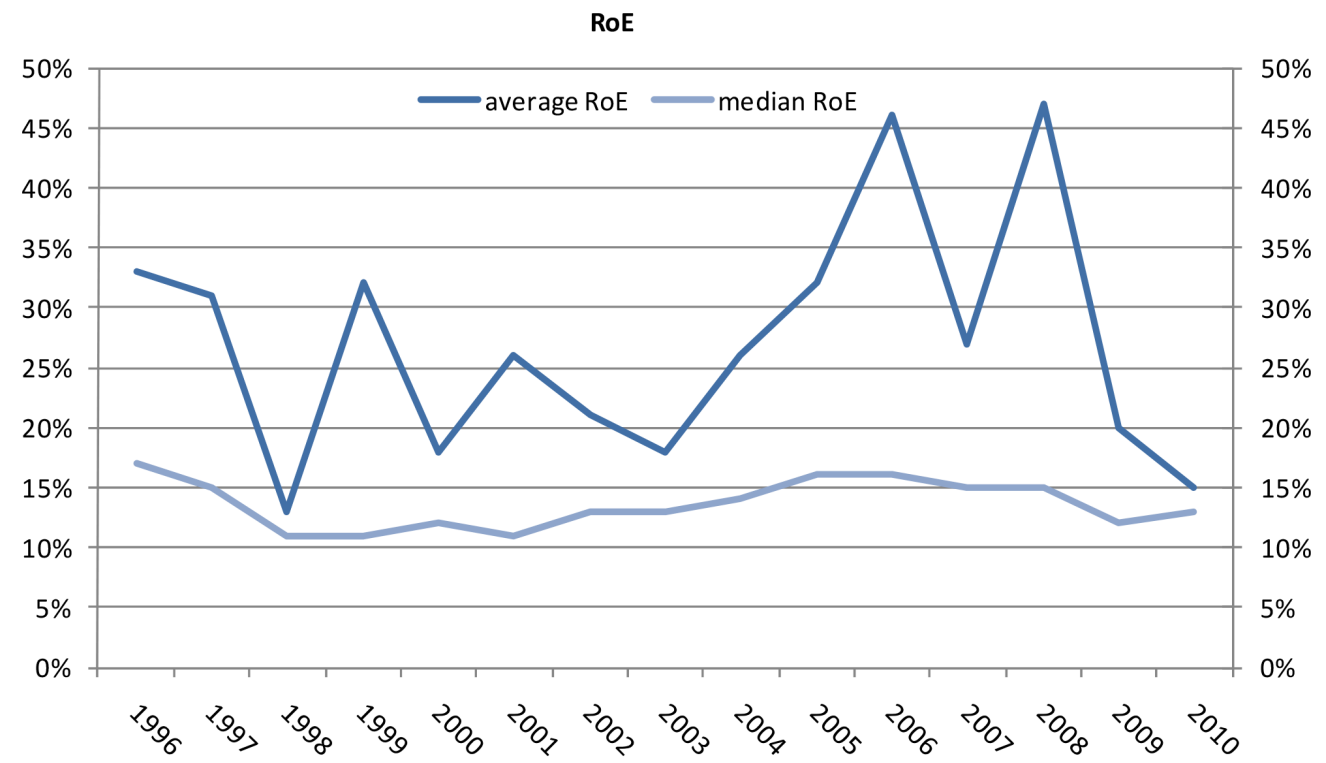

Figure 5. MFI RoE. Data from 1897 Microfinance Institutions extracted only from MFIs with positive RoE and positive Net Income after tax (Mix, 2011)

\subsection{High Interest Margin}

MFIs have higher net interest margins (Feasley, 2011) than commercial banks driven by the fact that the interests rate charged to its client on average are higher due to (Gupta \& Ramineedi, 2010b; Mersland \& Strom, 2011):

- Informal lender competition is present on the low income market segment, but the rates charged by the informal lenders are even higher, the quality of the service is poor and the perception of the clients is well below that of the MFIs.

- High operational cost ratio that makes MFIs to need to charge high interest rates to its clients.

- Most of the final borrowers of the MFIs are microenterprises with high returns

\subsection{Strong Asset Quality}

Statistically MFIs have stronger asset quality than global commercial banks or than emerging markets mainstream banks (Gonzalez, 2009). The average write-off ratio from 1996 to 2009 for all the MFIs reporting to the MIX was $0.51 \%$. Notwithstanding at the beginning of 2010 the write off ratio sharply increased to $0.80 \%$. The write-off ratio of the UK banks on the first half of 2010 was $1.5 \%$, according to the Bank of England statistics.

\subsection{Risk Management Techniques}

Because the clients of the MFIs generally do not posses collateral as a guarantee for the loans, MFIs issue loans that are given for entrepreneurial activities and lending decisions are based 
on personal characteristics, credit history, group pressure and business cash flow, instead on collaterals, business capital or holdings. In order to encourage the repayment of the microcredits, MFIs involve the community, group lending (Feasley, 2011). One of the most powerful tools used in the loan concession process is the shared liability group, in which several borrowers of the same community but from different families grant a common guarantee to the lender. The social pressure that this schema puts on borrowers reduces the default probability. Other effective management techniques are:

- Small loan amounts

- Borrower diversification

- Large client base

- Short loan maturities

- Interviews to family, neighbours, clients and providers

- Very small proportion of consumer loans, MFIs concentrate mostly on microenterprises lending

\section{MFIs Capital and the Financial Crisis}

The MFI sector earned its reputation as a countercyclical industry in the Asian Financial crisis of the late 1990 (Patten, 2001) although recently MFIs loans delinquency levels increased from January 2008 to January. But MFIs low leverage ratio (high proportion of equity against total assets), the fact that the average maturity of the liabilities is longer and more stable than the average maturity of assets, increase its stability against financial crisis. Additionally MFIs keep a high proportion of benefits as loss reserves and maintain a very prudent dividend policy. In general solvency is not a concern for listed MFIs whose ratios are very strong (Hamilton et al 2009). Leverage or equity over asset ratios in 2010 (Total Equity/Total Assets) reached 23.2\%. As a comparison, solvency in banks of developed countries measured as Tier I levels vary from $7 \%$ to $14 \%$ and measured as total Equity/Total Assets is in the range of $3.7 \%$ to $5 \%$ (MIX database survey, 2010). It is worth to mention that also for profit international investors have demonstrated their commitment with the MFI sector, listed and unlisted, during the present financial crisis providing new equity when required and not selling the asset to reduce losses.

The graph below shows the better performance of an index composed of four listed MFIs (Compartamos Banco, Bank Rakyat Indonesia, SKS Microfinance and Equity Bank Kenya) since the inception of the financial crisis in November 2007, compared to the MSCI Global Financial Institutions Index and also compared to the MSCI Emerging Markets Financial Institutions Index 


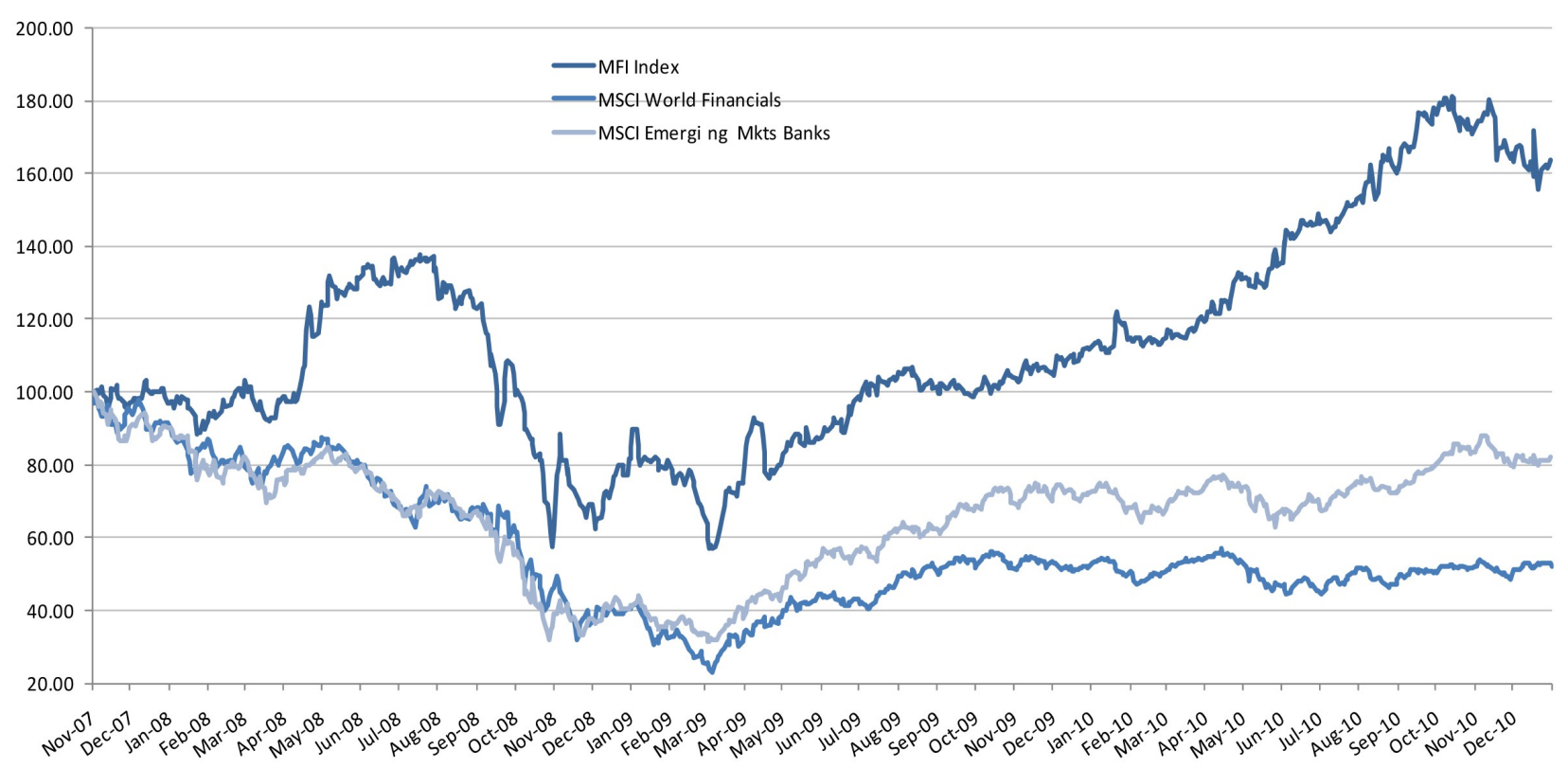

Figure 6. Performance of four listed MFIs vs the MSCI Global Financials Intuitions Index and the MSCI Emerging Markets Financials Intuitions Index

\section{Conclusions}

A further strong growth in the Microfinance industry is expected in the coming years since globally a very large number of poor people and microenterprises are underserved in terms of financial services and in particular in terms of loan products. Microfinance can be considered as one of the new frontiers of the global banking industry.

MFIs have a set of characteristics that could make them different to other financial institutions. These attributes may make them an interesting diversification asset subclass for international equity investors. Presently, international for-profit investors have very few ways of investing in microfinance equity. Most of the equity of the MFI equity is funded locally or thanks to the local public sector, our estimates show that only a fraction of the MFI equity are investments from international investors. The space for growth is important and international investors should play a relevant role in the future, but this requires listing in stock exchanges. The listing in stock markets can provide the MFIs with a new source of capital to maintain growth and to expand lending and therefore to reach new microfinance borrowers and help the development of the poorest population. The stock exchange listing should also drive the MFIs towards a more professional management, more transparency and to follow stricter regulations.

\section{References}

Brand, D. (2010): The Asset Class of Microfinance during the Financial Crisis. Swiss Banking Institute of the University of Zurich. 
Byerlee, D., \& de Janvry, A. (2008). Agriculture for development world. Development report. 2008 World Bank.

CGAP (2011). The consultative group to assist the poor. Available online at: http://www.cgap.com/data.

Cole, S., Simpson, T., \& Zia, B. (2009) Prices of Knowledge. What drives the Demand for Financial Services in Emerging Markets? Harvard Business School Working Papers, 09-117.

Dieckmann, R. (2008). Microfinance: An Attractive Dual Return Investment. Research Document, 1st October 2008. Deutsche Bank Research.

Dieckmann, R. (2009). Microfinance: An Emerging Investment Opportunity. Research Document, 19th December 2007. Deutsche Bank Research.

Feasley, A. (2011). SKS Microfinance and For-Profit MFIs, Unscrupulous Predators or Political Prey? Examining the Microfinance Credit Crunch in Andhra Pradesh and Assessing the Applicability of the UN Global Compact "Protect Respect Remedy" Framework. Cornell Law School Student Conference Papers. Paper 49. 11 April 2011.

Gonzalez, A. (2009). Microfinance at a Glance. Working Paper. Microfinance Information Exchange, MIX.

Gonzalez, A. (2010). Microfinance Funders Profiles. Working Paper. Microfinance Information Exchange, MIX. http://dx.doi.org/10.1596/1813-9450-5460

Gupta, A., \& Ramineedi, D. (2010a). India Financials Sector. Research Document, $15^{\text {th }}$ January 2010. Credit Suisse Research.

Gupta, A., \& Ramineedi, D. (2010b). SKS Microfinance: Banking the Unbanked. Research Document, 24th September 2010. Credit Suisse Research.

Hamilton, S. et al. (2009). Microfinance: Testing its Resilience to the Global Financial Crisis. Research Document, 22 Jan 2009. Fitch Ratings.

Hechler-Fay d'herbe, N., Luscher, Y. (2008). Microfinance investment vehicles MIVs. Research document, $4^{\text {th }}$ August 2008. Credit Suisse Research.

Mersland, R., \& Strom, O. (2011). What Drives the Microfinance Lending Rate. 10 May 2011. University of Groningen.

MIX (2011). Microfinance information exchange. Available online at: http://www.mixmarket.org 
Patten, R (2001). Microfinance Success Amidst Macroeconomic Failure: The experience of Bank Rakyat Indonesia during the Asian Crisis". World Development, 29. http://dx.doi.org/10.1016/S0305-750x(01)00016-X

Reille, X, \& Glisovic-Mezieres, J. (2009). Microfinance Funds Continue to Grow Despite the Crisis. Working Paper, April 2009. CGAP.

Rozeira de Mariz, F., \& Reille, X., Littlefield, E., \& Kneiding, C. (2009). Microfinance. Shedding light on microfinance equity valuation. Past and present. Research Document, $3^{\text {rd }}$ March 2010. JPMorgan \& CGAP.

Rozeira De Mariz, F., Reille, X., Littlefield, E., \& Kneiding, C. (2009). Microfinance. Shedding Light on Microfinance Equity Valuation. Past and Present. Research Document, 3rd February 2009. JPMorgan \& CGAP.

Rozeira De Mariz, F., Reille, X., Rozas, D., \& Kneiding, C. (2010). All Eyes on Microfinance Asset Quality. Microfinance Global Valuation Survery 2010. Research Document, 2nd March 2010. JPMorgan \& CGAP. 